\title{
Comparison of rapid immunodiagnosis assay kit with molecular and immunopathological approaches for diagnosis of rabies in cattle
}

\author{
Ajaz Ahmad and C. K. Singh \\ Department of Veterinary Pathology, College of Veterinary Science, Guru Angad Dev Veterinary and Animal Sciences \\ University, Ludhiana - 141 004, Punjab, India. \\ Corresponding author: Ajaz Ahmad, e-mail: ajazpatho786@gmail.com, \\ CKS: rabiesck@gmail.com \\ Received: 09-10-2015, Revised: 20-12-2015, Accepted: 28-12-2015, Published online: 31-01-2016
}

doi: 10.14202/vetworld.2016.107-112 How to cite this article: Ahmad A, Singh CK (2016), Comparison of rapid immunodiagnosis assay kit with molecular and immunopathological approaches for diagnosis of rabies in cattle, Veterinary World 9(1): 107-112.

\begin{abstract}
Aim: Presently, diagnosis of rabies is primarily based on, conventional fluorescent antibody technique (FAT), immunopathological and molecular techniques. Recently, rapid immunodiagnostic assay (RIDA) - A monoclonal antibodybased technique has been introduced for rapid diagnosis of rabies. The present investigation is envisaged to study the efficacy of RIDA kit for the diagnosis of rabies in cattle.
\end{abstract}

Materials and Methods: About 11 brain samples from cattle, clinically suspected for rabies, were screened by the FAT, Heminested reverse transcriptase polymerase chain reaction (HnRT-PCR), Immunohistochemistry (IHC), and RIDA.

Results: The sensitivity for detection of rabies from brain tissue by RIDA was $85.7 \%$ as compared to $100 \%$ by IHC as well as HnRT-PCR. The accuracy of detection of rabies by RIDA was $91.6 \%$ as compared to $100 \%$ that of IHC and HnRT-PCR, whereas specificity of RIDA was $100 \%$ like that of the IHC and HnRT-PCR.

Conclusion: Despite a comparatively low-sensitivity and accuracy of RIDA, latter can still be useful in screening a large number of field samples promptly. However, it is recommended that negative results with RIDA in cattle need to be authenticated by suitable alternative diagnostic approaches.

Keywords: cattle, diagnosis, fluorescent antibody technique, heminested reverse transcriptase, immunohistochemistry, rabies.

\section{Introduction}

Rabies is the most important zoonotic disease of animals that has a significant impact on human beings. Authentic diagnostic approaches, therefore, have to be employed to distinguish this disease from other encephalitic conditions.

A rapid immunodiagnostic assay (RIDA) using a specific monoclonal antibody against rabies virus (RABV) is commercially available (Bio note, Korea). RIDA kit is rapid and simple and does not require any special equipment or technical expertise [1]. The efficacy of the diagnostic kits might vary with different species.

Immunohistochemistry (IHC) is a sensitive diagnostic technique which can demonstrate rabies antigen in fixed paraffin embedded tissue sections. In cattle, the distribution of viral antigen was revealed either in granular form or as inclusion bodies in the cerebellum, brain stem, hippocampus, and cerebrum [2-4].

Copyright: Ahmad and Singh. Open Access. This article is distributed under the terms of the Creative Commons Attribution 4.0 International License (http://creativecommons.org/licenses/ by/4.0/), which permits unrestricted use, distribution, and reproduction in any medium, provided you give appropriate credit to the original author(s) and the source, provide a link to the Creative Commons license, and indicate if changes were made. The Creative Commons Public Domain Dedication waiver (http:// creativecommons.org/publicdomain/zero/1.0/) applies to the data made available in this article, unless otherwise stated.
Heminested reverse transcriptase polymerase chain reaction (HnRT-PCR) has been used to diagnose RABV worldwide due to its sensitivity and immense versatility and can even be useful for examining paraffin-fixed archived and decomposed samples [5]. The nucleoprotein $(\mathrm{N})$ gene of RABV is targeted for diagnosing and analyzing hereditary characteristics and antigenic properties since this gene is highly conserved and combined with encapsidation of genomic RNA [6,7]. Recently, RIDA - A monoclonal antibody-based technique has been introduced for rapid diagnosis of rabies. The efficacy of the assay might vary in different species.

The present study was, therefore, envisaged to study the efficacy of RIDA in cattle where in comparison of its sensitivity, specificity and accuracy of detection of RABV in clinically suspected cattle with molecular technique viz. HnRT-PCR and an immunopathological technique viz. IHC.

\section{Materials and Methods}

\section{Ethical approval}

The study was approved by Institutional Animal Ethics Committee under memo no. IAEC/2014/24170, Dated 04/12/14.

\section{Sample collection}

Brain tissue samples of cattle $(n=11)$ suspected for rabies were collected from post-mortem hall, Department of Veterinary Pathology, Guru Angad 
Dev Veterinary and Animal Sciences University (GADVASU), Ludhiana, Punjab and different dairy farms of Punjab, India, between January 2014 and January 2015 . All brain samples were stored at $-20^{\circ} \mathrm{C}$ in the laboratory for further processing. Diagnostic tests like fluorescent antibody technique (FAT), HnRTPCR and RIDA were carried out to detect the RABV infection. Direct FAT is a gold standard [8], thus, the sensitivity of RIDA kit was analyzed in comparison to FAT in brain tissue samples. For histopathology and $\mathrm{IHC}$, brain tissue samples were fixed and stored in $10 \%$ neutral buffered formalin for further analysis.

\section{Fluorescent antibody test}

FAT was carried out on fresh brain sample following the standard protocol [9]. Briefly, glass slides with impression smears of brain tissue were placed in coplin jar containing acetone and fixed at $-4^{\circ} \mathrm{C}$ for $1 \mathrm{~h}$. Positive slides from a known rabies positive case and negative slide from a normal and uninfected animal were used as a positive and negative control, respectively. The slides were air-dried, incubated with lyophilized anti-rabies nucleocapsid conjugate (Bio$\mathrm{Rad}$, France) for $35 \mathrm{~min}$ at $37^{\circ} \mathrm{C}$ in a humid chamber and washed with phosphate buffered saline (PBS) in three successive washes for 5-10 min. The slides were rinsed with distilled water, air-dried and a cover slip was mounted by adding buffered glycerol on the smear. The slides were visualized under an immunofluorescent microscope (Zeiss) for bright apple-green, round to oval bodies. Positive and negative controls were run together with the test specimens.

\section{Histopathology}

Brian tissues samples including cerebellum, cerebrum, and hippocampus were collected and fixed in $10 \%$ neutral buffered formalin solution and given overnight washings under tap water. Dehydration of samples was done through ascending grades of alcohol $(70 \%, 80 \%, 90 \%$, and absolute alcohol) followed by clearing with acetone. Tissues were embedded in paraffin wax (Leica Microsystem) for further processing. Approximately, 4-5 $\mu$ thick sections were cut, stained with routine hematoxylin and eosin ( $\mathrm{H}$ and E) staining technique [10] and examined by BX61 Research Photomicrograph Microscope System (Olympus Corporation, USA), the facility provided by the department.

\section{IHC}

Anti-rabbit polyclonal antisera raised in Rabies Research-cum-Diagnostic Laboratory of the Department of Veterinary Pathology, GADVASU, Ludhiana was used as primary antibody in IHC. Advanced $\mathrm{SS}^{\mathrm{TM}}$ One step polymer horseradish peroxidase (HRPO) IHC detection system (BioGenex Laboratories Inc., San Ramon, California, USA) counterstained with Gill's hematoxylin was used. IHC was done as recommended by the manufacturer with minor modifications. Formalin-fixed brain samples were thoroughly washed in running water; dehydrated in ascending grades of alcohol and acetone; cleared in benzene and embedded in paraffin at $58^{\circ} \mathrm{C}[11,12]$. Paraffin-embedded tissues were cut into $5 \mu \mathrm{m}$ thick sections, and sister sections were taken on Superfrost/ Plus, positively charged, microscopic slides (Fisher Scientific, USA). The sections were deparaffinized and rehydrated by immersing in $250 \mathrm{ml}$ EZ-AR common solution at $70^{\circ} \mathrm{C}$ for $10 \mathrm{~min}$ in EZ-Retriever R System V.2.1. Subsequent antigen retrieval was done in citrate buffer $(0.01 \mathrm{M}, \mathrm{pH} 6.0-6.2)$ at $95^{\circ} \mathrm{C}$ for $10 \mathrm{~min}$ and at $98^{\circ} \mathrm{C}$ for $5 \mathrm{~min}$ in EZ-Retriever R System V.2.1. Three washing were given in PBS buffer for 3 min each. The endogenous tissue peroxidases were inactivated by immersing slides in 3\% hydrogen peroxide solution in methanol for $15 \mathrm{~min}$ at room temperature in humid chamber followed by three washings with PBS buffer for 3 min each. Non-specific binding was blocked by incubating sections with ready-to-use power block for $10 \mathrm{~min}$ at room temperature in the moist chamber. On one section of each slide, primary polyclonal rabbit anti-rabies antibody of 1:1000 dilution (in PBS) was added, and slide was incubated for $1 \mathrm{~h}$ in moist chamber at room temperature, whereas, on the other section of each slide, PBS without primary antibody was added, so as to serve as a negative control. The sections were washed thrice in PBS buffer for $3 \mathrm{~min}$ each, and thereafter, incubated with polymer HRP (Super Sensitive label, One Step Polymer-HRPO Reagent) for $30 \mathrm{~min}$ at room temperature in the moist chamber, followed by three washing in PBS buffer for 3 min each. The antigen-antibody peroxidase reaction was developed with a freshly prepared 3,3-diaminobenzidine (DAB) solution by mixing two drops of $\mathrm{DAB}$ chromogen with $1 \mathrm{ml}$ of DAB buffer supplied by the manufacturer adding $5 \mathrm{ml}$ hydrogen peroxide. Sections were washed in distilled water for $5 \mathrm{~min}$ and counterstained with Gill's hematoxylin (Merck, Germany) for $30 \mathrm{~s}$ and washed in running tap water for $5 \mathrm{~min}$. Finally, the slides were dehydrated in ascending grades of alcohol, cleared in xylene, mounted in DPX and examined under an advanced microscope (BX 61, Olympus Corporation, USA).

\section{Extraction of viral RNA}

Total RNA was extracted from brain tissue using Trizol reagent (Invitrogen, USA) following manufacturer's instructions with minor modifications. Briefly, $0.1 \mathrm{~g}$ brain tissue was homogenized with $1 \mathrm{ml}$ Trizol and $200 \mu \mathrm{l}$ chloroform (Ambion Life Technologies, USA) was added. After centrifugation of the sample at $10,000 \mathrm{rpm}$ for $15 \mathrm{~min}$, the top aqueous layer was recovered, and RNA was precipitated by adding $0.5 \mathrm{ml}$ isopropanol. The sample was spun at $10,000 \mathrm{rpm}$ for $10 \mathrm{~min}$, the liquid removed and the pellet washed with $1 \mathrm{ml}$ of $75 \%$ ethanol. The dried RNA pellet was dissolved in $50 \mu 1$ sterile RNase free water. RNA concentration was measured using Nano Drop Spectrophotometer (Nano Drop Technologies, $\mathrm{CA}$ ) in $\mathrm{ng} / \mu \mathrm{l}$. The quality of RNA was checked as a 
ratio of OD $260 / 280$ and stored at $-80^{\circ} \mathrm{C}$. RNA was converted into cDNA using High-Capacity cDNA Reverse Transcription Kit with RNAse inhibitor (Applied Biosystems, USA).

\section{RNA Amplification}

Amplification of $2 \mu \mathrm{l}$ of reverse-transcribed cDNA template was performed in a final volume of $25 \mu 1 ; 12.5 \mu 1 \times 2$ PCR mix (GoTaq Green Master Mix, Promega), $1.0 \mu \mathrm{l}$ of each forward and reverse primer (JW12 and JW6) with 10 pmol concentration, and nuclease free water was added to make final volume of $25 \mu 1$. The amplification was performed in a thermal cycler with cycling conditions of initial denaturation at $94^{\circ} \mathrm{C}$ for $3 \mathrm{~min} ; 35$ cycles denaturation at $94^{\circ} \mathrm{C}$ for 30 seconds; annealing at $56^{\circ} \mathrm{C}$ for $45 \mathrm{~s}$ and elongation at $72^{\circ} \mathrm{C}$ for $20 \mathrm{~s}$. Final elongation was performed at $72^{\circ} \mathrm{C}$ for $3 \mathrm{~min}$. For HnRT-PCR, similar quantities of the PCR mixture constituents except $2 \mu$ of the primary PCR product as template and JW12 as forward and JW10 as reverse primer were used (Table-1). Thermocyclic conditions were kept same as that of primary PCR. PCR amplified products were visualized in $1 \%$ agarose gel electrophoresis after ethidium bromide staining of $586 \mathrm{bp}$ amplicons.

\section{RIDA kit}

A commercial RIDA kit was used the following the manufacturer's direction (Bionote, Korea). Briefly, a swab supplied with the kit was dipped into $10 \%$ homogenate of brain samples. The content of swab was shifted to an enclosed proprietary buffer of RIDA kit. A $100 \mu \mathrm{l}$ aliquot of the sample was transferred to the sample well. The appearance of two lines, $5 \mathrm{~min}$ after addition of the brain samples, was considered positive result whereas the formation of one line was considered as a negative result [13].

\section{Calculation of sensitivity, specificity, and accuracy}

Sensitivity was calculated as $[\mathrm{TP} /(\mathrm{TP}+\mathrm{FN})] \times$ 100. Specificity was calculated as $[\mathrm{TN} /(\mathrm{TN}+\mathrm{FP})] \times$ 100. Accuracy was calculated as $[\mathrm{TP}+\mathrm{TN} /$ $(\mathrm{TP}+\mathrm{FP}+\mathrm{FN}+\mathrm{TN})] \times 100$ wherein $\mathrm{TP}$ was true-positives; FN was false-negatives; TN was true negatives and FP was false positives as determined by the reference assay, i.e., FAT.

\section{Results}

Out of 11 cattle brain samples screened by FAT, only six cows (54.54\%) (07RL14, 15RL14, 19RL14, 21RL14, 42RL14 and 02RL15) were confirmed to be rabid (or TP). Same six samples were detected as positive by IHC as well as by HnRT-PCR. However, RIDA could detect rabies only in five samples. Further, the intensity of the test lines, in positive samples, also varied in different field samples. The sensitivity of detection of rabies by IHC, HnRT-PCR, and RIDA was $100 \%, 100 \%$ and $85.71 \%$ respectively (Table- 2 ). Specificity of detection of rabies by IHC, HnRT-PCR, and RIDA was $100 \%$ in all the tests. The accuracy of detection of rabies by IHC and HnRT-PCR was $100 \%$ and by RIDA, was $91.66 \%$ (Tables-3-5).

As such, sensitivity for detection of rabies from brain tissue by RIDA was comparatively lower $(85.7 \%)$ as compared to IHC as well as HnRT-PCR $(100 \%)$. Likewise, accuracy for detection of rabies by RIDA was also lesser (91.6\%) as compared to IHC and HnRT-PCR (100\%), whereas specificity of RIDA $(100 \%)$ was comparable to IHC and HnRT-PCR (100\%) (Table-6).

\section{Discussion}

FAT

Direct FAT is gold-standard for rabies diagnosis as recommended by the World Health Organization and Office International des Epizootics [14]. Bright apple-green, round to oval intracellular fluorescent bodies were observed in all the positive brain samples as observed earlier [15].

\section{Histopathology}

Neuronal necrosis, Negri bodies (Figure-1), satellitosis, gliosis, neuronophagia, congestion, hemorrhage, and perivascular cuffing observed in brain samples was in accordance with the findings of Singh [16] and Sumedha [17].

\section{IHC}

IHC in formalin fixed paraffin embedded tissue sections has been reported to be a sensitive

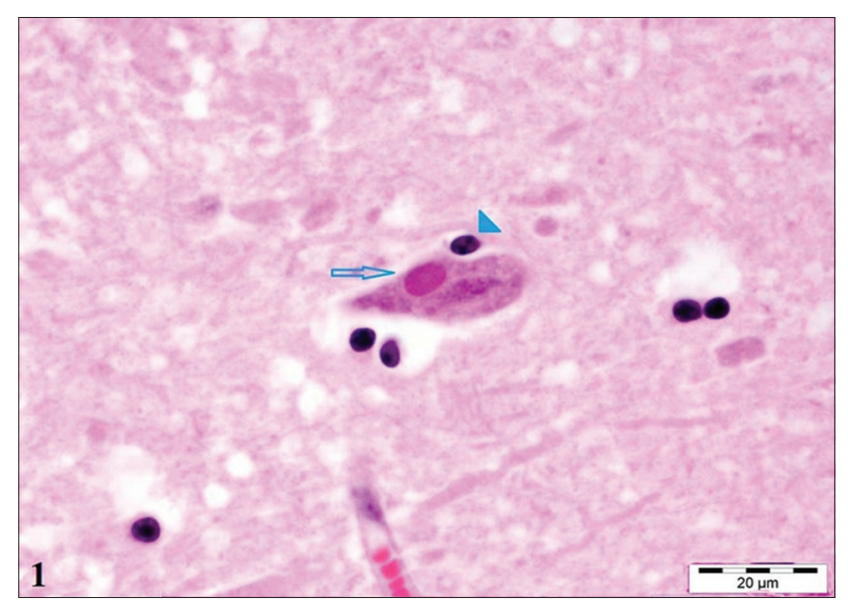

Figure-1: Section of the hippocampus of rabid cattle showing sharply Negri body and neuronophagia $(\times 100)$.

Table-1: Primers used for HnRT-PCR to target $\mathrm{N}$ gene.

\begin{tabular}{llccc}
\hline Primer & Nucleotide sequences (5'-3') & Nucleotide position & Sense & Size of amplicon (bp) \\
\hline JW 12 & 5'ATGTAACACCCCTACAATG3' & $55-73$ & + & 586 \\
JW 6 & 5'CAATTGGCACACATTTTGTG3' & $660-641$ & - & \\
JW 10 & 5'GTCATCAGAGTATGGTGTTC3' & $636-617$ & - & \\
\hline
\end{tabular}

HnRT-PCR $=$ Hemi-nested reverse transcriptase polymerase chain reaction 
technique for detection of rabies antigen [18] and has been found to be of immense value for retrospective studies $[19,20]$. With IHC viral antigens were observed as fine granules in the cytoplasm of the neurons (Figure-2), which were not clearly visible with $\mathrm{H}$ and $\mathrm{E}$ staining.

\section{HnRT-PCR}

In the present study, $100 \%$ agreement was observed between FAT and HnRT-PCR targeting N gene of virus (Figure-3). HnRT-PCR using a primer set that amplified the $\mathrm{N}$ gene of RABV was able to detect the isolates from six cows confirmed to be rabid by FAT. These isolates were detected only after both primary as well as secondary PCRs were accomplished in the assay of HnRT-PCR as reported earlier $[21,22]$.

\section{RIDA}

The present study evaluated the efficacy of RIDA for diagnosis of rabies for use in field condition. RIDA detected rabies (Figure-4) in cattle brain samples with a sensitivity of $85.71 \%$. The result obtained in the present study is comparable to earlier usage of RIDA kit on European mammals wherein the sensitivity of $88 \%$ reported [23]. Nevertheless, higher sensitivity of $91 \%$

Table-2: Test results of IHC, HnRT-PCR and RIDA in comparison with FAT.

\begin{tabular}{|c|c|c|c|c|c|c|c|}
\hline \multirow[t]{2}{*}{ FAT } & \multicolumn{2}{|c|}{ IHC } & \multicolumn{2}{|c|}{ HnRT-PCR } & \multicolumn{2}{|c|}{ RIDA } & \multirow[t]{2}{*}{ Total } \\
\hline & $\mathbf{P}$ & $\mathbf{N}$ & $\mathbf{P}$ & $\mathbf{N}$ & $\mathbf{P}$ & $\mathbf{N}$ & \\
\hline$P$ & 06 & 00 & 06 & 00 & 05 & 01 & 06 [TP] \\
\hline $\mathrm{N}$ & 00 & 05 & 00 & 05 & 00 & 05 & $05[\mathrm{TN}]$ \\
\hline Total & 06 & 05 & 06 & 05 & 05 & 06 & 11 \\
\hline
\end{tabular}

IHC=Immunohistochemistry, HnRT-PCR=Heminested polymerase chain reaction, $\mathrm{RIDA}=$ Rapid immunodiagnostic assay, FAT=Fluorescent antibody test, $\mathrm{P}=$ Positive, $\mathrm{N}=$ Negative, $\mathrm{TP}=$ True positive, $\mathrm{TN}=$ True negative was also reported, in another study, wherein, 54 brain samples were tested [24]. Despite a comparatively low sensitivity and accuracy of RIDA, it is still of use

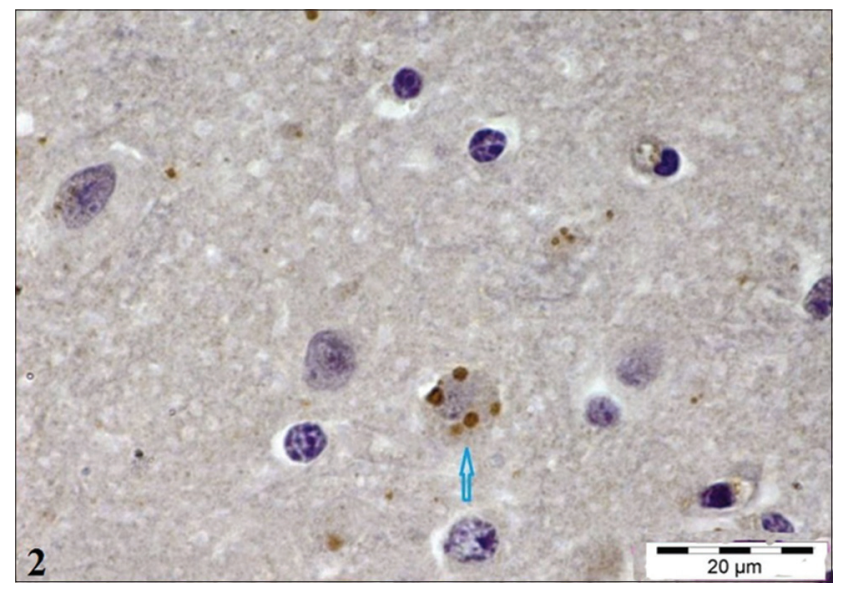

Figure-2: Section of the cerebellum of rabid cattle showing brown colored Negri bodies in the purkinje cells $(\times 100)$.

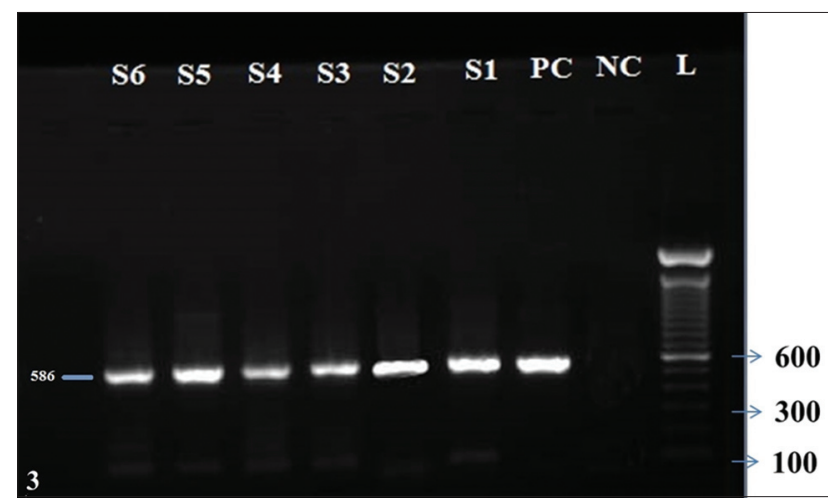

Figure-3: Agarose gel (1\%) stained with ethidium bromide. Lane $L$ is the 100 bp ladder, NC is the negative control, PC is a positive control, S1-S6 are the samples that are positive for fluorescent antibody technique.

Table-3: Test results of RIDA.

\begin{tabular}{llcc}
\hline Factors & Formula & Calculation & Result (\%) \\
\hline Sensitivity & TP/(TP+FN) $] \times 100$ & $5 / 5+1=5 / 6$ & 85.71 \\
Specificity & {$[\mathrm{TN} /(\mathrm{TN}+\mathrm{FP})] \times 100$} & $5 / 5+0=5 / 5$ & 100 \\
Accuracy & $\mathrm{TP}+\mathrm{TN} /(\mathrm{TP}+\mathrm{FP}+\mathrm{FN}+\mathrm{TN})] \times 100$ & $6+5 / 6+0+1+5$ & 91.66 \\
\hline
\end{tabular}

$\mathrm{TP}=$ True positive, $\mathrm{TN}=$ True negative, $\mathrm{FP}=$ False positive, $\mathrm{FN}=$ False negative, $\mathrm{RIDA}=$ Rapid immunodiagnostic assay

Table-4: Test results of HnRT-PCR.

\begin{tabular}{llcr}
\hline Factors & Formula & Calculation & Result (\%) \\
\hline Sensitivity & TP $/(T P+F N)] \times 100$ & $6 / 6+0=6 / 6$ & 100 \\
Specificity & {$[T N /(T N+F P)] \times 100$} & $5 / 5+0=5 / 5$ & 100 \\
Accuracy & TP+TN/(TP+FP+FN+TN) $] \times 100$ & $6+5 / 6+0+0+5=11 / 11$ & 100 \\
\hline
\end{tabular}

$\mathrm{TP}=$ True positive, $\mathrm{TN}=$ True negative, $\mathrm{FP}=$ False positive, $\mathrm{FN}=$ False negative, HnRT-PCR=Heminested polymerase chain reaction

Table-5: Test results of IHC.

\begin{tabular}{llcr}
\hline Factors & Formula & Calculation & Result (\%) \\
\hline Sensitivity & TP $/(T P+F N)] \times 100$ & $6 / 6+0=6 / 6$ & 100 \\
Specificity & {$[T N /(T N+F P)] \times 100$} & $5 / 5+0=5 / 5$ & 100 \\
Accuracy & TP+TN/(TP+FP+FN+TN) $\times 100$ & $6+5 / 6+0+0+5=11 / 11$ & 100 \\
\hline
\end{tabular}

$\mathrm{TP}=$ True positive, $\mathrm{TN}=$ True negative, $\mathrm{FP}=$ False positive, $\mathrm{FN}=$ False negative, $\mathrm{IHC}=$ Immunohistochemistry 
Table-6: Comparison of sensitivity, specificity and accuracy of three diagnostic techniques.

\begin{tabular}{lccc}
\hline Factors & IHC (\%) & HnRT-PCR (\%) & RIDA (\%) \\
\hline Sensitivity & 100.00 & 100.00 & 85.71 \\
Specificity & 100.00 & 100.00 & 100.00 \\
Accuracy & 100.00 & 100.00 & 91.66
\end{tabular}

IHC=Immunohistochemistry, HnRT-PCR=Heminested polymerase chain reaction, RIDA=Rapid immunodiagnostic assay

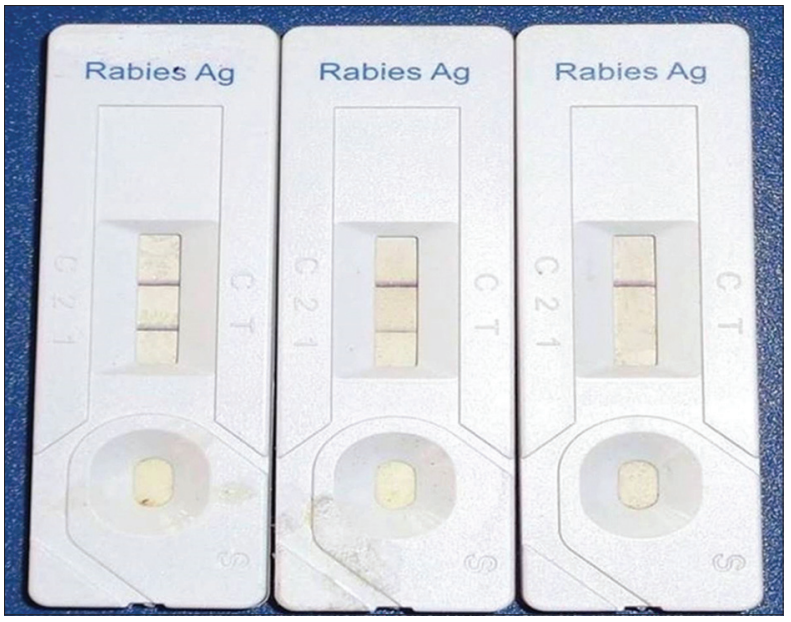

Figure-4: Rapid immunodiagnostic assay $A$ and $B$ are positive and $C$ is negative.

to screen a large number of field samples promptly. It is, however, recommended that any negative result with RIDA should be ruled out by confirmation with a suitable alternative diagnostic approach.

\section{Conclusion}

It is possible to use RIDA for prompt diagnosis of rabies in the field conditions. However, the samples found negative by RIDA need to be investigated further by immunofluorescent/molecular approach for authentication/confirmation of the diagnosis of rabies.

\section{Authors' Contributions}

CKS designed the experiment, organized sample collection. The experiment was performed by AA under the supervision of CKS. AA collected samples and performed the diagnostic techniques. Both authors read and approved the final manuscript.

\section{Acknowledgments}

The authors are thankful to the Director of Research, Guru Angad Dev Veterinary and Animal Sciences University, Ludhiana for providing the necessary facilities and fund for this study.

\section{Competing Interests} interests.

The authors declare that they have no competing

\section{References}

1. Lembo, T., Niezgoda, M., Velasco-Villa, A., Cleaveland, S., Ernest, E. and Rupprecht, C.E. (2006) Evaluation of a direct, rapid immunohistochemical test for rabies diagnosis. Emerg. Infect. Dis., 12: 310-313.

2. Sharma, P., Singh, C.K., Sood, N.K., Sandhu, B.S., Gupta, K. and Brar, A.P.S. (2014) Diagnosis of rabies from brain: Comparison of histochemical and histopathological approaches. Indian J. Vet. Pathol., 38(4): 269-272.

3. Wahan, S., Sandhu, B.S., Singh, C.K., Gupta, K., Sood, N.K. and Kaw, A. (2012) Comparison of clinico-pathological, immunohistochemical and immunofluorescent techniques for diagnosis of rabies in animals. Indian J. Anim. Sci., 82(1), 3-8.

4. Sandhu, B.S., Sood, N.K., Awahan, S., Singh, C.K. and Gupta, K. (2011) Immunohistochemistry, histopathology, quantitative morphometry of Negri bodies in the brain of rabid animals. Indian J. Vet. Pathol., 35(2): 117-122.

5. David, D., Yakobson, B., Rotenberg, D., Dveres, N., Davidson, I. and Stram, Y. (2002) Rabies virus detection by RT-PCR in decomposed naturally infected brains. Vet Microbiol., 87: 111-118.

6. Yang, J., Hooper, D.C., Wunner, W.H., Koprowski, H. and Dietzschold, B.F. (1998) The specificity of rabies virus RNA encapsidation by nucleoprotein. Virology, 242: 107-117.

7. Pranoti, S., Singh, C.K. and Deepti, N. (2015) Comparison of immunochromatographic diagnostic test with heminested reverse transcriptase polymerase chain reaction for detection of rabies virus from brain samples of various species. Vet. World, 8(2): 135-138.

8. WHO. (1992) Expert Committee on Rabies. $8^{\text {th }}$ Report. WHO Technical Report Series, No. 824. World Health Organization, Geneva. p7, 8.

9. Meslin, F.X., Kaplan, M.M. and Koprowski, H. (1996) Laboratory Diagnosis of Rabies. WHO, Geneva. p88-95.

10. Luna, L.G. (1968) Manual of Histological Staining Methods of the Armed Forces Institute of Pathology. $3^{\text {rd }}$ ed. The Blakiston Division, McGraw-Hill Book Co., New York.

11. Pranoti, S., Singh, C.K., Sood, N.K., Gupta, K., Sandhu, B.S. and Brar, A.P.S. (2015) Immunohistochemical detection of rabies in dogs from skin. Indian J. Canine Pract., 7(1): 37-40.

12. Pedroso,P.M.O., Pescador, C.A., Bandarra, P.M., Raymundo, D.L., Borba, M.R., Wouters, F., Bezerra-Junior, P.S. and Driemeier, D. (2008) Standardization of immunohistochemistry technique for detection of rabies virus in formalin-fixed and paraffin-embedded tissue samples from central nervous system of cattle. Pesqui. Vet. Bras. 28(12): 627.

13. Dong, K.Y., Eun, K.S., Yoon, I.O., Kyung, W.L., Chung, S.L., Seo, Y.K., Jeong, A.L. and Jae, Y.S. (2012) Comparison of four diagnostic methods for detecting rabies viruses circulating in Korea. J. Vet. Sci., 13(1): 43-48.

14. Dean, D.J., Abelseth, M.K. and Atanasiu, P. (1996) The fluorescent antibody test. In: Meslin, F.X., Kaplan, M.M. and Koprowski, H., editors. Laboratory Techniques in Rabies. $4^{\text {th }}$ ed. WHO, Geneva. p88-95.

15. Ehizibolo, D.O., Nwosuh, C., Ehizibolo, E.E. and Kia, G.S.N. (2009) Comparison of the fluorescent antibody test and direct microscopic examination for rabies diagnosis at the National Veterinary Research Institute, Vom, Nigeria. Afr. J. Biomed. Res., 12: 1.

16. Singh, H. (1999) Experimental rabies in buffalo calves with street rabies virus. M.V.Sc. Thesis, Punjab Agricultural University, Ludhiana, India.

17. Sumedha, A. (2010) Anti-mortem and post-mortem detection of rabies virus antigen in natural cases of rabies in animals - An immunopathological study. M.V.Sc. Thesis. Guru Angad Dev Veterinary and Animal Sciences University, Ludhiana, India.

18. Last, R.D., Jardine, J.E., Smit, M.M.E. and Van Der Lugt, J.J. (1994) Application of immunoperoxidase techniques to formalin-fixed brain tissue for the diagnosis of rabies in southern Africa. J. Vet. Res., 61(2): 183-187. 
19. Gunawardena, G.S.P. and Blakemore, W.F. (2007) Proceedings of the Peradeniya University Research Sessions, Sri Lanka. Vol. 12. No. 1.p168.

20. Rissi, D.R., Fighera, R.A., Irigoyen, L.F., Kommers, G.D. and Claudio, S.L.B. (2008) Occurrence of rabies in sheep in Rio Grande do Sul, Brazil. Pesqui. Vet. Bras., 28(10): 495.

21. Soares, R.M., Bernardi, F., Sakamoto, S.M., Heinemann, M.B., Cortez, A., Alves, L.M., Meyer, A.D., Ito, F.H. and Richtzenhain, L.J. (2002) A heminested polymerase chain reaction for the detection of Brazilian rabies isolates from vampire bats and herbivores. Mem. Inst. Oswaldo Cruz, 97: 109-111.

22. Orłowska, A., Smreczak, M., Trębas, P. and Żmudziński, J.F.
(2008) Comparison of real-time PCR and heminested RT-PCR methods in the detection of rabies virus infection in bats and terrestrial animals. Bull. Vet. Inst. Pulawy, 52: 313-318.

23. Servat, A., Picard-Meyer, E., Robardet, E., Muzniece, Z., Must, K. and Cliquet, F. (2012) Evaluation of a rapid immunochromatographic diagnostic test for the detection of rabies from brain material of European mammals. Biologicals, 40(1): 61-66.

24. Kang, B., Oh, J., Lee, C., Park, B.K., Park, Y., Hong, K., Lee, K., Cho, B. and Song, D. (2007) Evaluation of a rapid immunodiagnostic test kit for rabies virus. J. Virol. Methods, 145(1): 30-36.

$* * * * * * * *$ 